https://doi.org/10.38129/Ann.Yur.Ist.2020.4.2.16

УДК 314.06(314.7.044): 314.8.062.2:340.141

\title{
ОЧЕРК О КЛИМАТЕ, БОЛЕЗНЯХ И ИХ ВЛИЯНИИ НА СРЕДНЕВЕКОВУЮ ДЕМОГРАФИЮ
}

\author{
ЯКОВ РИЕР (Могилев, Республика Беларусь) *
}

Климатические изменения в последние десятилетия стали объектом пристального общественного внимания. Тема глобального потепления - общее место и в публицистике, и в научной литературе. Но распространенное суждение о влиянии на современный климат антропогенного фактора человеческой деятельности - нельзя принять, ибо оно опровергается многочисленными погодными колебаниями в прошлом.

Собственно, именно внимание к причинам нынешних климатических процессов способствовало активизации изучения истории климата Земли, знания о котором углубились теперь на многие тысячелетия в прошлое. В итоге появившееся среди климатологов и подхваченное многими экологистами и политиками в конце прошлого века суждение о резком потеплении в наше время из-за парникового эффекта, отраженное в популярном графике американского климатолога Майкла Манна (т. наз. «клюшка Манна»), было расценено как фальсификация с целью получения финансирования.

Стремясь наглядно продемонстрировать наступившее глобальное потепление, последний убрал из своего графика детализацию, заменив ее линией, демонстрирующей общий температурный тренд, «потеряв» при этом «период потепления, который пережила Европа 1 тыс. - 700 лет назад и «малый ледниковый период» в Европе (начался в XVII веке, продлился до середины XIX-го)»1. В итоге исчезли реальные климатические колебания. Но ведь именно они определяли восприятие погоды современниками.

\footnotetext{
${ }^{1}$ Mann M. E., Bradley R. S., Hughes M. K. Global-scale temperature patterns and climate forcing over the past six centuries // Nature. No. 392. 23 April 1998. P. 779-787; http:/ / www.polit.ru/lectures/2010/12/01/climat.html; http:/ / www.washprofile.org/ru/node/6605; http:/ / www.kataklizmic.narod.ru/faktu.html.
} 
Дискуссии о потеплении и его причинах продолжаются. Становится неочевидной роль в потеплении концентрации $\mathrm{CO}_{2}$, что снижает роль антропогенного фактора 2 . Кстати, весь пафос спора о глобальном потеплении связан с невозможностью установления нынешнего климатического тренда изза хаотичных ежегодных погодных колебаний. И если климатологи с их нынешними знаниями спорят, то что говорить о древних... Тенденции становились понятными спустя десятилетия и то, если были стабильными. Тогда они замечались людьми, и те реагировали хозяйственными, поселенческими, политическими и иными изменениями. Соответственно, на исторические процессы влияли лишь устойчивые, то есть длительные тренды, существенно менявшие природные условия. К частным и частым колебаниям люди привыкали ${ }^{3}$.

Точные же графики с широкими амплитудами колебаний демонстрируют чуть ли не броуново движение температур (если, к тому же, учесть, что эти температуры определены по косвенным признакам: годичные кольца деревьев, ледниковые скважины и то лишь в отдельных регионах Северного полушария; экстраполяция этих данных на оба полушария требует признания и локальных различий). Вспомним, что все последние годы погода существенно разнится на западе и востоке Европы. Причем более экстремальной она оказывается ближе к Атлантике: снежные заносы зимой и паводки летом заметнее в Англии, Франции и даже Испании. Наоборот, экстремально жаркое лето 2010 года наблюдалось в Восточной Европе, на западе же континента жара оказалась более умеренной. И в завершающемся году жара, охватившая все северное полушарие, все же существенно отличалась по регионам. Такой же разброс данных мог, естественно, быть в прежние эпохи.

Особо на жизнь людей погода влияла, понятно, в доиндустриальный период, когда основным источником существования было сельское хозяйство, обеспечение продовольствием. Климатические циклы средневековой эпохи уже известны. Как видно на предлагаемом графике (рис. 1), существенное похолодание начала Средневековья сменилось в $X$ в. теплым периодом, продлившимся почти до середины тысячелетия, хотя и прерывавшееся отдельными холодными периодами. Именно в середине I тыс. н. э. произошли

2 Cм., н напр.: $\quad$ http://www.lenta.ru/news/2011/11/22/warm/; http://www.lenta.ru/news/2011/11/25/carbon/.

3 Риер Я. Г. Аграрный мир Восточной и Центральной Европы в средние века по археологическим данным. Могилев. 2000. С. 20. 
падение Западной Римской империи и общий упадок Южной Европы. Дальнейшее потепление породило «климатический оптимум» X-XII вв., который стал временем восстановления европейской хозяйственной и общественной жизни, создания государств и роста городов. Последнее стало возможным в том числе и вследствие подъема сельского хозяйства, которое и сумело обеспечивать продовольствием горожан, а также - растущие феодальные элиты. «Малый ледниковый период» продлившийся (при отдельных колебаниях) до XIX в., уже существенно не влиял на жизнь населения Европы, в том числе и благодаря развитию городской экономики и созданной во времена Высокого Средневековья инфраструктуры: устойчивой сети поселений и дорог.

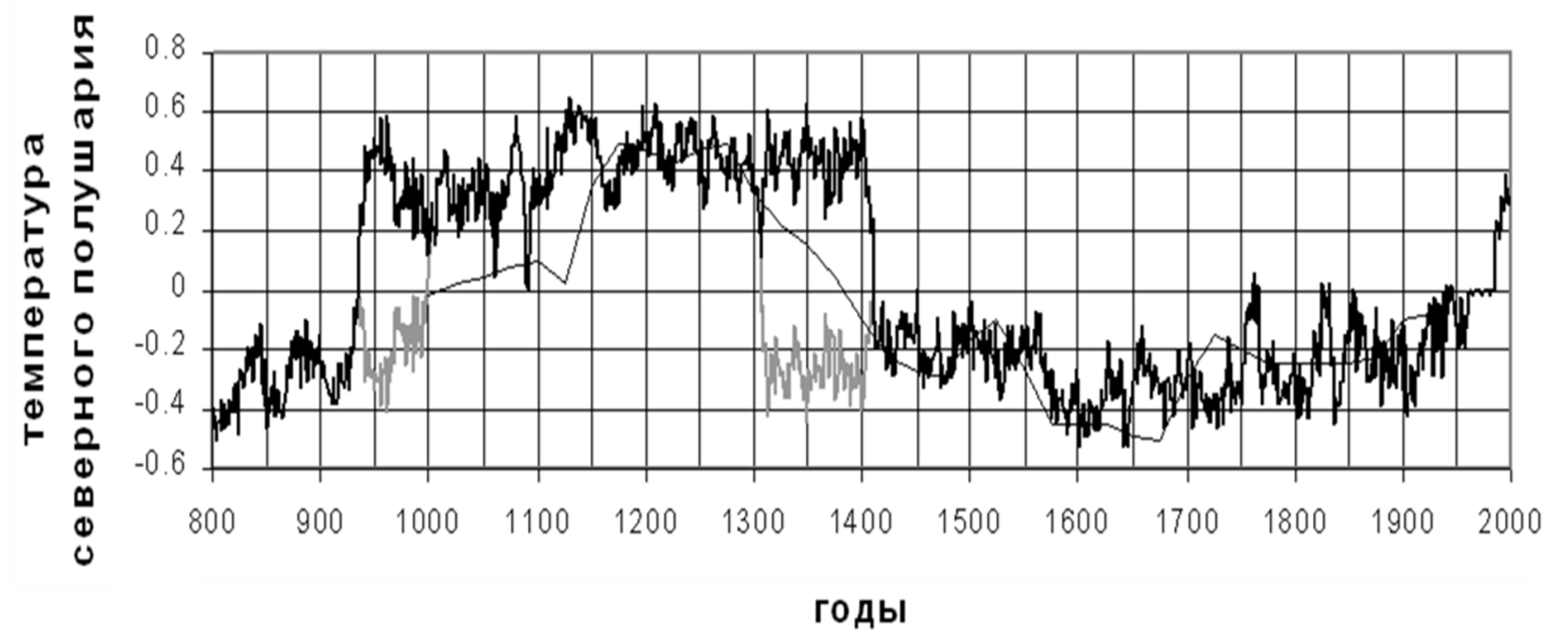

Рис. 1. Температура Северного полушария в IX-XX4.

Хотя, естественно нельзя идеализировать ту эпоху. Голодовки и вызванные ими эпидемии сотрясали Европу вплоть до XIX в.

Климатические колебания также существенно влияли на динамику и плотность расселения. Европейские данные отражены на рис. 2.

\footnotetext{
${ }^{4}$ Lamb H. H. Climate: Present, Past, and Future. // L.: Barnes and Noble Publ., 1977. Vol. 2; Даценко Н. М., Иващенко Н. Н. Учет нелинейности отклика дендрохронологических рядов на изменения температуры воздуха при тысячелетних реконструкциях климата. // Тр. Гидрометцентра России. 2005. Вып. 340. С. 68-76.
} 


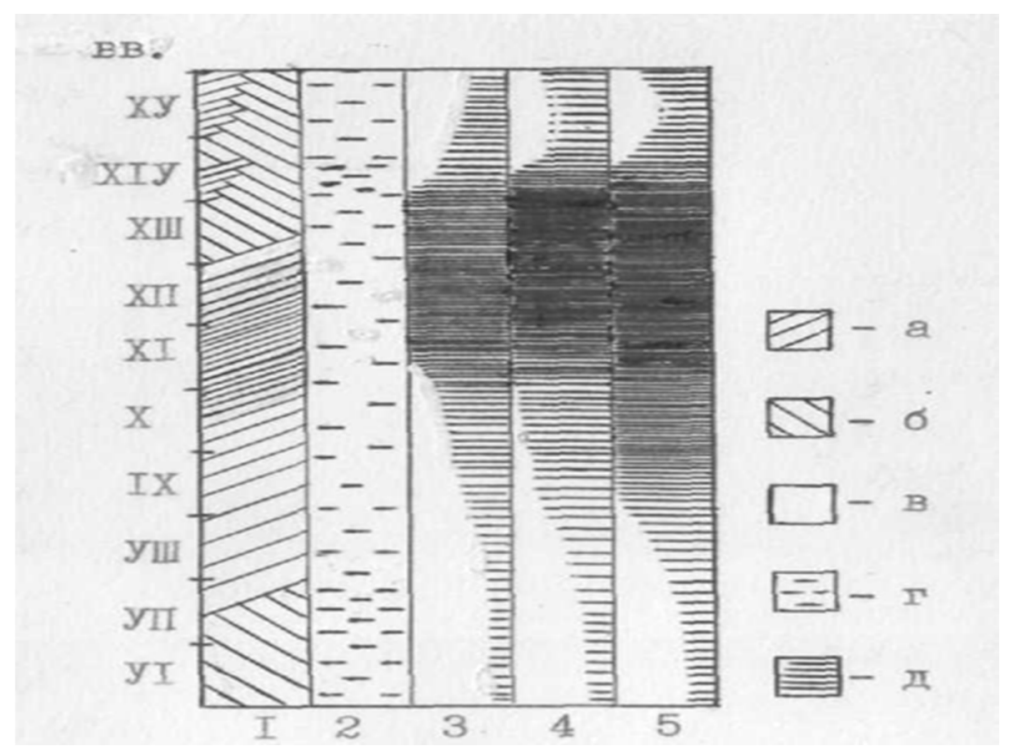

Рис. 2. Климат и заселенность в центральной и восточной Европе с VI по XV в.*

Примітки: I - температура, 2 - уровень влажности, 3 - расселение в восточнославянских землях, 4 - расселение в западнославянских землях, 5 расселение в древнегермансках землях; а - теплый период, б - холодное время, в - засушливые века, г - периоды с повышенной влажностью, д - динамика расселения заселенности ${ }^{5}$.

*Плотность шттриховки означает интенсивность процессов.

Рост населения во времена «климатического оптимума» привел к формированию в Западной Европе современного аграрного пейзажа уже к XIV в., когда возникли почти все существующие современные деревни и были освоены прежде поросшие лесами возвышенности. В Центральной Европе, где населенной менее плотно, аналогичные процессы отмечены в XIV-XVI вв., а в восточной части континента, при еще более редком населении - в XVII-XVIII вв. Кстати, именно мягкий атлантический климат Западной Европы способствовал не только ее более плотной заселенности уже с Раннего Средневековья, но сложению там обособленных крестьянских хозяйств в первой половине I тыс. н. э. Ибо в таком климате отдельная крестьянская семья могла самостоятельно себя прокормить, в отличие от населения Восточной Европы, континентальный климат которой способствовал устойчивости общинных связей и коллективистских представлений вплоть до столыпинской аграрной реформы, встреченной враждебно многими крестьянами. То есть

5 Риер Я. Г. Археология средневековой европейской деревни: общие черты и региональные особенности. Могилев. 2008. С. 10. 
природная среда существенно повлияла на социальное и политическое развитие разных регионов Европы.

Но в рамках общих тенденций влияние на людей оказывали и локальные колебания климата. Исследования последнего времени позволяют не только уточнить сведения об этих колебаниях, но и выявить их причины. Как оказалось, из 20 самых холодных лет за всю средневековую эпоху 13 приходятся на VI в., после 536 года. Недавнее изучение добытых из специально пробуренных в ледниках кернољ льда показало, что причиной похолодания в тот год стало мощное извержение вулкана где-то в высоких широтах северного полушария. В 540 и 547 гг. произошло еще два извержения, что сделало 540-е гг. самым холодным десятилетием за 2300 лет: средняя температура тогда составила около $11,8^{\circ} \mathrm{C}$ (для сравнения средняя общемировая температура 2015 года равнялась $\left.14,8^{\circ} \mathrm{C}\right)$. Причиной послужили частицы вулканической пыли в атмосфере, отражавшие солнечное излучение. Холодный климат этого столетия мог стать одним из факторов, повлиявших на изменения в обществе.

В частности, длительные неурожаи и голод в Центральной Азии вызывали миграции населения оттуда в Китай и Восточную Европу, тем самым способствуя распространению чумы, эпидемия которой в 551-580 гг. охватила Восточную Римскую империю и державу Сасанидов в Иране, и стала известной под названием «Юстинианова чума». Впрочем, недавние исследования генетиков показали, что впервые ДНК чумной бактерии появились в Европе примерно 4800 лет назад одновременно с началом масштабного переселения в Центральную Европу жителей каспийско-причерноморских степей носителей индоевропейских языков, согласно распространенной гипотезе. По мнению генетиков, именно тогда чума и попала в Европу, где затем образовался собственный природный резервуар чумных бактерий. В дальнейшем этот очаг продолжал пополняться бактериями из Центральной Азии.

В период правления императора Юстиниана чума попала в Константинополь с кораблями, возившими в столицу хлеб из Египта. Первые случаи заболевания в Константинополе отмечаются в 544 году. Чума быстро охватила Европу и Северную Африку. Эта эпидемия продолжалась до середины VIII в. Только в Европе, по разным оценкам, она унесла жизни от 25 до 50 млн. человек.

Биограф Юстиниана Прокопий Кесарийский, писал, что впервые болезнь была отмечена в африканском городе Пелузии (в восточной части дельты 
Нила). Хлебные поля Египта кормили Константинополь. На кораблях, доставлявших зерно, плыли и крысы, и блохи - переносчики бактерий чумы. Из Константинополя чума распространилась по всей Европе и Северной Африке. Епископ VI в. Григорий Турский описывал ее в «Истории франков»: «А уж во время самой чумы такая смертность была во всей той области, что и невозможно сосчитать, какое множество ююдей там погибло. И в самом деле, когда уже не стало хватать гробов и досок, то погребали $b$ одну могилу по десять и более человек. Подсчитали, что $b$ базилике святого Петра [в Клермоне] $b$ одно из воскресений было триста покойников. И сама смерть была внезапной. А именно: когда появлялась рана наподобие змеи в паху или под мышкой, человек так отравлялся ядом, что он испускал дух на второй или третий день. Сила яда лишала человека сознания». Упоминания об этой эпидемии есть и в средневековых ирландских хрониках. Среди ее жертв были римский папа и валлийский король.

Бактерия - переносчик бубонной чумы появилась в Центральной Азии, постоянно присутствовала в колониях грызунов, таких как сурки или песчанки, которые жили рядом с людьми. Генетические данные свидетельствуют о том, что штамм, вызвавший чуму Юстиниана, возник где-то вблизи западного Китая. Он впервые появился на южных берегах Средиземного моря и, по всей вероятности, распространялся вдоль южных, морских торговых сетей, по которым везли шелк и специи для римских потребителей. Эти условия были примером ранней глобализации, и как только штамм достиг колоний грызунов, обитавших в зернохранилищах империи, смертность стала колоссальной.

Анализируя последствия этой эпидемии, ученые считают, что чума помешала продолжить завоевания Юстиниана в западной части бывшей Римской империи и что она же ослабила государство настолько, что поспособствовала победам арабов над византийцами и захвату ими Палестины, Сирии, Египта и Ирана. Другие авторы обвиняют чуму и в помощи англо-саксонскому завоеванию Британии, кельтское население которой пострадало от эпидемии. Утихая в одних местностях и охватывая другие, порой возвращаясь, эпидемия чумы продолжалась, как отмечалось, до середины VIII в.

Еще более разрушительной была эпидемия чумы в середине XIV в. Распространенное объяснение обширности и губительности этой эпидемии состоит в том, что эту болезнь вызывали укусы чумных блох, паразитировавших на крысах, которые в средневековом мире жили повсюду.

Наиболее катастрофической в Европе была чумная эпидемия 1346-1353 гг., названная современниками «Черной смертью». Но произведенное недавно 
группой шведских и итальянских ученых компьютерное моделирование распространения эпидемии в городах Европы позволило им предположить, что «Черную смерть» в Европе разносили люди, а не крысы. «Болезнь бы не распространилась так быстро, если бы передавалась крысами. В случае с крысами путь распространения болезни более длинный, тогда как, передаваясь от человека $\kappa$ человеку, все происходило быстрее», отметил один из исследователей.

«Черная смерть» унесла жизни 30-50\% населения пораженных болезнью стран. Абсолютные цифры колеблются в пределах от 25 до 75 млн. человек. Разбежка данных, помимо понятных пробелов и неточности средневековой статистики объясняется неравномерностью распространения и смертности от болезни. В отдельных местностях и, особенно, городах констатировали почти повальную убыль населения - до 90\%, в других - намного меньшую.

Одной из причин такой катастрофической смертности в Европе французский историк П. Тубер считает рост населения, опередивший в XIV в. возможности его тогдашнего обеспечения, что вело к массовому появлению физически ослабленных людей и известной скученности жителей в городах при крайне низком тогда уровне гигиены. Следует добавить, что симптомы «Черной смерти» не совпадают полностью с признаками современной чумы, очаги которой все еще существуют в Азии, Африке и странах Южной Америки, где сохраняются очаги зараженных грызунов.

Последствия чумы неизмеримы в плане демографическом, экономическом, социокультурном, религиозном, социально-психологическом. Известный историк медицины Ж. Сурниа утверждает, что они сравнимы с атомной войной. Пандемия привела Европу в состояние демографической катастрофы. В особенности пострадали города, ибо в условиях городской скученности болезнь распространялась быстрее. Но и аграрный мир Европы также пришел в критическое состояние: земля оставалась невозделанной, нехватка рабочих рук в сельском хозяйстве привела к массовому падежу скота и эпизоотиям.

Попытки преодоления экономического кризиса путем законодательного регулирования вызывали к жизни жесточайшие меры, например, англииское рабочее законодательство Эдуарда III и Рччарда II, запрещуавшее бродяжничество и попрошайничество, наказанием за которые было клеймление и обращение в рабство.

«Черная смерть» показала, как изменяется поведение человека в критической ситуации. С 1348 года в Европе наблюдаются эпизоды коллективной паники, массовые психозы, галлюцинации. «Почетный авторитет как божеских, так и человеческих законов почти упал и исчез», - с горечью отмечает современник событий, итальянский писатель Джованни Боккаччо. Для «человека перед лицом смерти» девальвировались религиозные 
и нравственные нормы: «Не станем говорить о том, что один горожанин избегал другого, что сосед почти не заботился о соседе, родственники посещцали друг друга редко или никогда, или виделись издали: бедствие воспитало в сердизах мужчин и женщиин такой ужас, что брат покидал брата, дядя племянника, сестра брата и нередко жена мужа: более того и вернее - отцы и матери избегали навешуать своих детей и ходить за ними, как будто то были не их дети». По многим линиям происходил разлом отношений человека с официальной церковью, на которую возлагалась вина за Господнюю кару. Чума вызвала к жизни новые еретические течения. По городам Франции и Германии двигались процессии флагеллантов. «Черная смерть» повлекла за собой вспышку антисемитизма: евреев обвиняли в злонамеренном отравлении колодцев с целью вызвать мор. В булле папы Климента IV говорилось, что евреи так же, как и христиане, умирают от чумы, а следовательно, не являются ее виновниками. Но эта булла не положила конец преследованиям.

В дальнейшем чума периодически возвращалась в Европу, но уже менее катастрофичными вспышками, которые происходили, постепенно затухая, каждые 20-30 лет, когда вырастали поколения, не пережившие предыдущие эпидемии и не получившие иммунитета. Трагично, что при этом умирали именно молодые. И такие вспышки преследовали европейцев (и не только их) до XVIII в. Так «Черная смерть» существенно замедлила демографическое развитие Европы, население которой в Средние века и без того росло крайне медленно.

Погодные изменения, пожалуй, помогли Чингисхану занять известное место в истории. Имеется в виду изменение азиатского климата с холодного и засушливого, предшествовавшего его восхождению как правителя Монгольской империи, на более теплый и влажный, позволивший всадникам из Средней Азии расширить границы его владений.

Ученые, исследовавшие фрагменты древних сибирских сосен в Центральной Монголии, возраст которых составляет около 2000 лет, полагают, что восхождение Чингисхана к власти точно совпадает с периодом выпадения необычно большого количества осадков, и такой период продолжался около двух десятилетий, что и позволило расцвести засушливым пастбищам, расположенным в азиатских степях. Появившиеся более обширные выпасы для табунов боевых лошадей, от которых зависел кочевой образ жизни монголов, помогли захватническим армиям Чингисхана установить свой контроль над территориями, простиравшимися от Китая на востоке, до Афганистана на юге и до Венгрии на западе. 
Годичные кольца, свидетельствующие о хорошем или плохом росте растений, указывают на то, что в период примерно с 1180 по 1190 гг., который непосредственно предшествовал правлению Чингисхана, происходили сильнейшие засухи, и в результате, вероятно, усилилась политическая нестабильность, способствовавшая его приходу к власти. После этого, как показывают годичные кольца, наступил устойчивый период дождей и мягкой погоды, продолжавшийся с 1211 по 1225 гг., и он точно совпал со стремительным взлетом империи Чингисхана.

Это была, естественно, не единственная причина, но изменение климата, судя по всему, создало идеальные условия для харизматичного лидера, позволив ему появиться из хаоса, создать армию и сконцентрировать в своих руках власть. «В засушливых местах необычная Влажность приводит к необычно обильной вегетации, которая трансорормируется $b$ лошадиные силы. Чингисхану $b$ буквальном смысле удалось оседлать эту волну»6. Затем, по анализу годичных колец, климат вновь вернулся к своему обычному холодному и сухому состоянию, что привело к засухам и низкой продуктивности пастбищ, и, в свою очередь, способствовало упадку империи при потомках Чингиза. А как повлияли завоевания монголов на жизнь народов тогдашней Восточной Европы и Азии, известно. Менее известно, что и в Центральной Европе завоеватели тоже изрядно «наследили»: прежде всего имеется в виду Венгрия, в которой монголы находились с весны 1241 года до лета 1242 года. Восстановилась страна после этого лишь спустя полстолетия. Кстати, на неожиданный уход завоевателей из Паннонской равнины - единственной в Европе (кроме Северного Причерноморья) степной зоны, повлияла необычно снежная зима с бурным таянием снега весной, что превратило Паннонскую степь в сплошное болото. И лошадей стало нечем кормить. Естественно, были и политические причины ухода - ссора хана Батыя со своими братьями. Но и погода сыграла свою роль.

Здесь приведены лишь отдельные примеры, но и они свидетельствуют: исторические процессы столь многофакторны, что их анализ требует междисциплинарных исследований, совместной работы историков с целым рядом специалистов разных направлений.

\footnotetext{
${ }^{6}$ См.: Риер Я. Г. Новое в исторической демографии [Электронный ресурс]: методические материалы / Я. Г. Риер. - Электрон. данные. - Могилев : МГУ имени А. А. Кулешова, 2018.
} 
Dr. habil. Yakov Rier (Mogilev, Belarus)

\section{Essay on the impact of climate and diseases on medieval demography}

The article is devoted to the most important issues of historical and legal medieval studies - the influence of climate and disease on the formation of the economic and demographic agenda. In particular, the author calls for a more extensive look at the problems of «global warming», given the presence of climatic cycles. In addition, the author emphasizes: political processes and, accordingly, many laws of past years and today are formed under the influence of natural environmental trends.

Key words: Middle Ages, Demography, Global Warming, Influence of Climate, Political Reflections.

Профессор Яков Риер (Могилев, Беларусь)

\section{Очерк о климате, болезнях и их влиянии на средневековую демографию}

Статья посвящена важнейшим вопросам историко-правовой медиевистики влиянию климата и болезней на формирование экономико-демографической повестки. В частности, автор призывает смотреть более пространно на проблематику «глобального потепления», учитывая наличие климатических циклов. Кроме того, автор подчеркивает: политические процессы и, соответственно, многие законы прошлых лет и дня сегодняшнего формируются именно под влиянием естественных, энвайронменталистских тенденций.

Ключевые слова: Средневековье, демография, глобальное потепление, влияние климата, политические рефлексии.

\section{Професор Яків Рієр (Могилів, Білорусь)}

\section{Нарис про клімат, хвороби та їхній вплив на середньовічну демографію}

Стаття присвячена найважливішому питанню історико-правової медієвістики - впливу клімату і хвороб на формування економіко-демографічного порядку денного. Зокрема, автор закликає аналізувати широко розрекламовану проблематику «глобального потепління» 3 огляду на наявність кліматичних циклів. Крім того, автор підкреслює: політичні процеси і, відповідно, багато законів минулих років і сьогодення формуються саме під впливом природних, енвайронменталістських тенденщій.

Ключові слова: Середньовіччя, демографія, глобальне потепління, вплив клімату, політичні рефлексії. 
* Риер Яков Григорьевич - доктор исторических наук, профессор кафедры всеобщей истории, экс-заведующий кафедрой всеобей истории Могилевского государственного университета имени А. А. Кулешова. E-mail: rier47@tut.by. 